\title{
Different bone anchorages for Morse taper implants with different lengths in maxilla
}

\section{anterior: An in silico analysis}

\author{
Diferentes ancoragens ósseas para implantes cone Morse variando os comprimentos em maxila \\ anterior: Uma análise in sílico \\ Diferentes anclajes óseos para implantes de cono Morse con diferentes longitudes en el maxilar \\ anterior: Un análisis in silico
}

Received: 06/30/2021 | Reviewed: 07/09/2021 | Accept: 07/27/2021 | Published: 08/03/2021

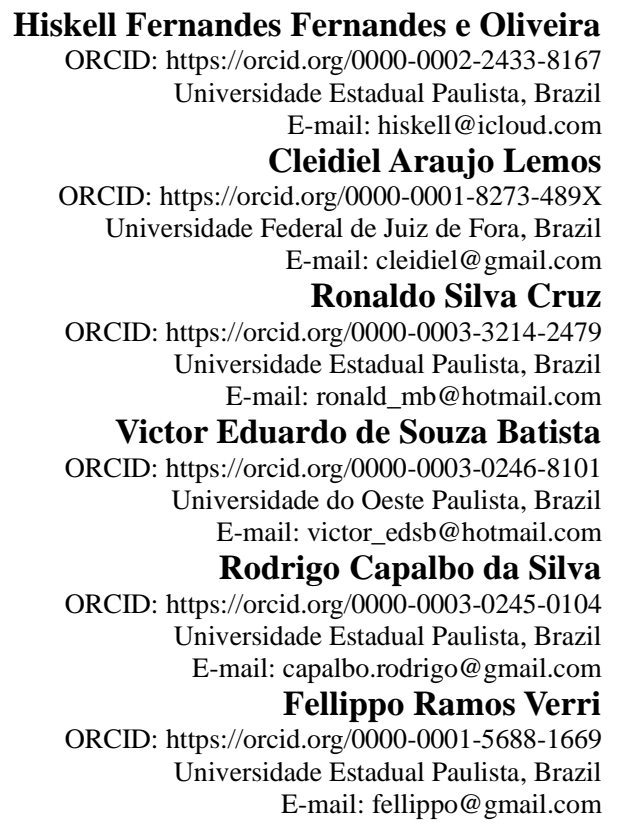

\begin{abstract}
This study aimed to evaluate the stress distribution in bone tissue, in Morse tapper implants and components supporting a single crown in the maxillary anterior area, under different bone anchorages (conventional, bicortical and bicortical with nasal floor elevation) and implant lengths $(8.5 \mathrm{~mm}, 10 \mathrm{~mm}$ and $11.5 \mathrm{~mm})$ using 3D finite element analyses. Three 3D models including element \#11 were simulated using software InVesalius, Rhinoceros 3D and SolidWorks. Bone block models were reconstructed from computed tomography and simulated the placement of one implant of $4 \mathrm{~mm}$ of diameter and lengths above mentioned, supporting cemented zirconia crown. The 3D models were processed by the finite element FEMAP and NeiNastran software, using a load of $178 \mathrm{~N}$ were applied at $0^{\circ}, 30^{\circ}$ and $60^{\circ}$, considering the implant long axis. Results were visualized as the von Mises stress, maximum principal stress and microstrain maps. Bicortical bone anchorages showed lower stress and microstrain bone tissue when compared to conventional bone anchorage. However, no differences were observed between bicortical and nasal floor elevation. Regarding implants and components, the stress distribution was similar between models with little stress relief in the apical region of the implants for implants with conventional anchorage. The conclusion drawn from this study is that non-axial loading showed worse biomechanical behavior for bone tissue and implants/components. The bicortical techniques (bicortical and nasal floor elevation) should be preferred during the implant placement to reduce the stress and microstrain in the bone tissue.
\end{abstract}

Keywords: Dental implants; Finite element analysis; Bone tissue.

\section{Resumo}

O objetivo deste estudo foi avaliar a distribuição de estresse em implantes cone morse, no tecido ósseo e em coroas unitárias na região anterior da maxila, em diferentes ancoragens ósseas (convencional, bicortical e bicortical com levantamento de assoalho nasal) utilizando a metodologia de elementos finitos 3D variando o comprimento dos implantes $(8.5 \mathrm{~mm}, 10 \mathrm{~mm}, 11,5 \mathrm{~mm})$. Três modelos 3D, incluindo o elemento \#11, foram simulados usando o software 
InVesalius, Rhinoceros 3D e SolidWorks. Modelos de blocos ósseos foram reconstruídos a partir da tomografia computadorizada e simularam a instalação de um implante de $4 \mathrm{~mm}$ de diâmetro e comprimentos acima mencionados, suportando coroa de zircônia cimentada. Os modelos 3D foram processados nos softwares de elementos finitos FEMAP e NeiNastran, utilizando uma carga de $178 \mathrm{~N}$ foram aplicados a $0^{\circ}, 30^{\circ}$ e $60^{\circ}$, considerando o longo eixo do implante. Os resultados foram visualizados como mapas de tensão de von Mises, a tensão máxima principal e microdeformação. As ancoragens ósseas bicorticais apresentaram menor estresse e microdeformação do tecido ósseo quando comparadas à ancoragem óssea convencional. No entanto, não foram observadas diferenças entre a elevação bicortical e do assoalho nasal. Em relação aos implantes e componentes, a distribuição de tensões foi semelhante entre os modelos com pouco alívio de tensões na região apical dos implantes para ancoragem convencional. Concluímos cargas oblíquas apresentam pior comportamento biomecânico para tecido ósseo e implantes/componentes. As técnicas bicorticais (elevação bicortical e do assoalho nasal) devem ser preferidas durante a instalação do implante para reduzir o estresse e a microdeformação no tecido ósseo.

Palavras-chave: Implantes dentários; Análise de elementos finitos; Tecido ósseo.

\section{Resumen}

Este estudio tuvo como objetivo evaluar la distribución de tensiones en tejido óseo, en implantes Morse y componentes que sostienen una corona en la zona anterior maxilar, bajo diferentes anclajes óseos (convencional, bicortical y bicortical con elevación nasal) y longitudes de implante $(8,5 \mathrm{~mm}, 10 \mathrm{~mm}$ y $11,5 \mathrm{~mm})$ utilizando análisis de elementos finitos 3D. Se simularon tres modelos 3D, incluido el elemento 11, utilizando el software InVesalius, Rhinoceros 3D y SolidWorks. Se reconstruyeron modelos de bloques óseos a partir de tomografía computarizada y se simuló la colocación de un implante de $4 \mathrm{~mm}$ de diámetro y longitudes antes mencionadas, soportando la corona de circonio cementado. Los modelos 3D fueron procesados por el software de elementos finitos FEMAP y NeiNastran, utilizando una carga de $178 \mathrm{~N}$ se aplicaron a $0^{\circ}, 30^{\circ}$ y $60^{\circ}$, considerando el eje largo del implante. Los resultados se visualizaron como el estrés de von Mises, el estrés principal máximo y microdeformación. Los anclajes óseos bicorticales mostraron menor tensión y microesfuerzo del tejido óseo en comparación con el convencional. No se observaron diferencias entre la elevación bicortical y del piso nasal. En cuanto a implantes y componentes, la distribución de tensiones fue similar entre modelos con escaso alivio de tensiones en la región apical de los implantes con anclaje convencional. llegamos a la conclusión de que es que la carga no axial mostró un peor comportamiento biomecánico para el tejido óseo y los implantes/componentes. Se deben preferir las técnicas bicorticales durante la colocación del implante para reducir la tensión y la microesfuerzo.

Palabras clave: Implantes dentales; Análisis de elementos finitos; Tejido óseo.

\section{Introduction}

Nowadays, oral rehabilitation with dental implants in maxillary anterior region demands a high aesthetic and functional perspective, which combined with experience of professional lead to the treatment success (Mazor et al., 2012). In this context, Morse taper implants could be indicated for single crown restorations with an excellent clinical and aesthetic result for maxillary anterior region (Mangano et al., 2012). The primary stability is considered an important factor to success of rehabilitation with dental implants, especially when installed with immediate loading (Ahn et al., 2012), in the anterior region with low bone density (Goiato et al., 2014). Different techniques of bone anchorage are used to increase primary stability in maxillary anterior region, such as bicorticalization (with or without nasal floor elevation) of dental implants (Mazor et al., 2012; Ahn et al., 2012; Verri et al., 2017), especially when the height of bone tissue is unavailable (Mazor et al., 2012).

Previous studies reported that bicortical techniques provide better stresses distribution in bone tissue around the implant (Verri et al., 2017; Verri et al., 2016; Verri et al., 2017(2)). However, this subject remains unclear, since some studies reported that the bicorticalization technique could increase the stress in the cortical bone tissue (Ivanoff et al., 2000; Kan et al., 2015). The previous studies that evaluating the effect of bicortical techniques maintained the length of implants. However, the choice of anchorage technique is associated with the length of implant that should be used, since the bone availability may not allow the placement of longer implants (Lemos et al., 2016). So, could be recommended surgical techniques, such as bicortical techniques to placement of longer implants. Although, the literature is scarce about the association of bone anchorage technique and the length of the implants, especially for Morse taper implants that present better stress distribution when compared to other connections (Santiago Junior et al., 2016). 
Finite element analysis (FEA) enables simulation of different situations to assessment of biomechanical behavior, mainly in implantology (Kan et al., 2015; Lemos et al., 2016; Huang et al.,2009; Minatel et al., 2017; de Souza Batista et al., 2017; de Souza Batista et al., 2017 (2); Verri et al., 2016) including some specific analysis of some structures (Verri et al., 2017; Verri et al., 2016; Verri et al., 2017(2); Verri et al., 2015). Therefore, FEA is considered a useful tool for studying stress distribution in implantology. So, the aim of this study was to evaluate the stress distribution in Morse taper implants, varying the bone anchorage (conventional, bicortical, bicortical with nasal floor elevation) and length of the implants using 3D FEA. The null hypothesis was that there is no influence on the stress distribution among the different surgical techniques evaluated.

\section{Methodology}

Three 3D models were created to represent different clinical situations. Each model simulated a bone block that received an implant of element \#11 with different surgical techniques according different lengths of the implant (Table 1). The bone block was simulated based on the decomposition of a computed tomography of the anterior maxillary region using InVesalius software (CTI Renato Archer, Capinas, SP, Brazil), which was composed of trabecular bone in the center and a cortical bone (1 mm) surrounded to simulate bone type III (Lekholm et al., 1985). The simulated models were imported in the Rhinoceros 3D software for simplification with standard bone block height fixed in $10.0 \mathrm{~mm}$ (Figure 1).

Table 1: Description of the models used in the study.

\begin{tabular}{|c|c|c|c|c|}
\hline Models & Technique & $\begin{array}{l}\text { Diameter and length } \\
\text { (Implants) }\end{array}$ & Load & Angulation \\
\hline M1 & Convencional & $4,0 \times 8,5 \mathrm{~mm}$ & $178 \mathrm{~N}$ & $\begin{array}{c}0^{\circ} \\
30^{\circ} \\
60^{\circ} \\
\end{array}$ \\
\hline M2 & Bicortical & $4,0 \times 10 \mathrm{~mm}$ & $178 \mathrm{~N}$ & $\begin{array}{c}0^{\circ} \\
30^{\circ} \\
60^{\circ}\end{array}$ \\
\hline M3 & Nasal floor elevation & $4,0 \times 11,5 \mathrm{~mm}$ & $178 \mathrm{~N}$ & $\begin{array}{c}0^{\circ} \\
30^{\circ} \\
60^{\circ}\end{array}$ \\
\hline
\end{tabular}

Source: Authors.

Figure 1: Schematic diagram of the models and the application of forces and constraints.

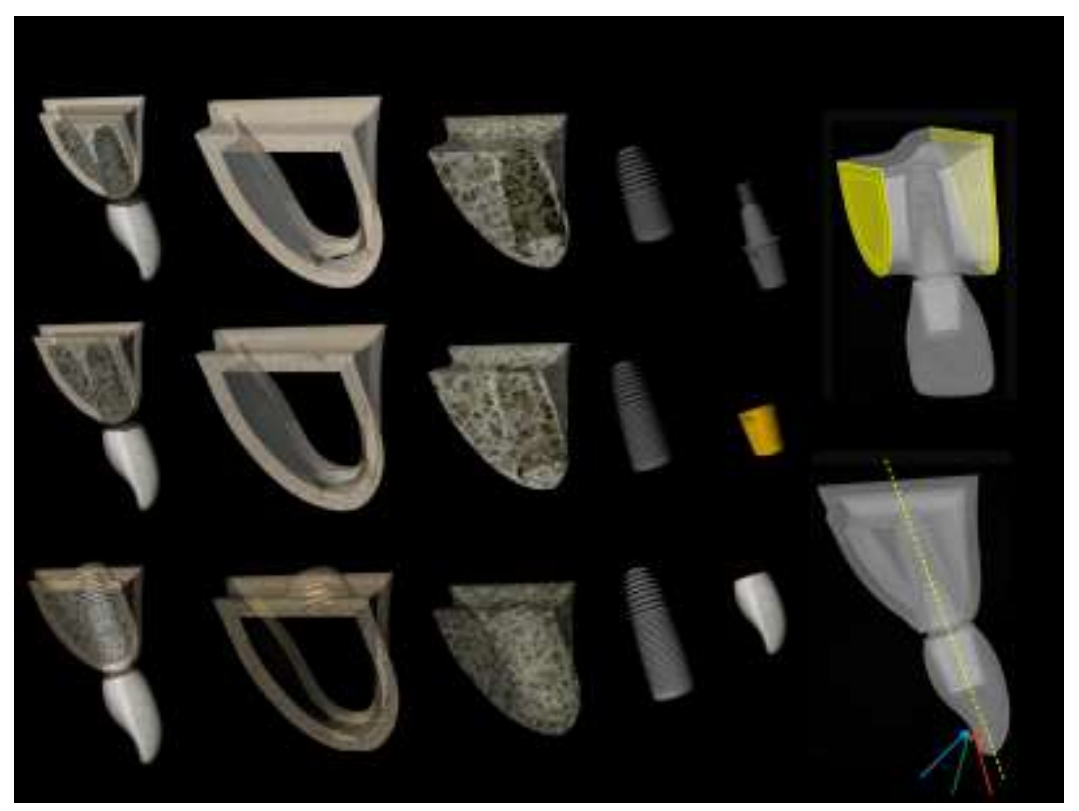

Source: Authors. 
The implants and components design were obtained of an original Morse taper implant (Conexão Sistema de Prótese Ltda., São Paulo, Brasil) of $4 \mathrm{~mm}$ diameter and different lengths: $8.5 \mathrm{~mm}, 10 \mathrm{~mm}$ and $11.5 \mathrm{~mm}$. The geometry of structures were simplified using Solidworks 2010 (SolidWorks Corp, Waltham, MA, USA) and Rhinoceros 4.0 software (NURBS Modeling for Windows, Seattle, WA, USA).

The simulated crown was modeled according previous studies (Verri et al., 2017; Verri et al., 2016), adapted under a prefabricated abutments, to receive the cemented ceramic zirconia crown. The dimensions of the prosthetic crown were simulated by a reduction of $1 \mathrm{~mm}$ of thickness in the vestibular and palatal surfaces and $2.0 \mathrm{~mm}$ in the incisal surface. In addition, the cement layer was simulated with $0.09 \mathrm{~mm}$ of average thickness, simulating resinous type (Lazari et al 2014).

After the modeling, the drawings were imported into the finite element FEMAP v.11.3.2 software to discretization of simulated finite element models. In this program the meshes (tetrahedral parabolic solid elements) of each structure were generated. Furthermore, the mechanical properties (modulus of elasticity and Poisson's ratio) of each material were incorporated according to the literature (Table 2). All materials were considered isotropic, homogeneous and linearly elastic, with all simulated contacts of bonded type.

Table 2: Properties of the materials involved in the study.

\begin{tabular}{cccc}
\hline Material & $\begin{array}{c}\text { Elastic Modulus } \\
(\mathrm{E}) \\
(\mathrm{GPa})\end{array}$ & Poisson's ratio (v) & References \\
\hline Trabecular bone & 1,370 & 0,30 & Sevimay et al. (2005) \\
\hline Cortical bone & 13,700 & 0,30 & Sertgöz et al. (1997) \\
\hline Titanium & 110,000 & 0,35 & Sertgöz et al. (1997) \\
\hline $\begin{array}{c}\text { Zirconia crown } \\
(\text { e.max ZirCAD) }\end{array}$ & 205,000 & 0,22 & Lazari et al (2014) \\
\hline Resin Cement & 18,300 & & Lazari et al (2014) \\
\hline
\end{tabular}

Source: Authors.

The applied load used in the study was $178 \mathrm{~N}$ at $0^{\circ}, 30^{\circ}$ and $60^{\circ}$ in terms of the long axis of the implant localized 2 mm below the incisal surface of teeth (Verri et al., 2017; Verri et al., 2017 (2)). The boundary conditions were established as fixed in all axes ( $\mathrm{x}, \mathrm{y}$ and $\mathrm{z}$ directions) at constrictions lines of bone block. All the contacts were symmetric weld with excepting the abutment/implant contact which was considered as symmetric contact.

After the preparation, models were exported to NeiNastran 11.0 (Noran Engineerring, Inc., Califórnia, EUA) to solve analysis. After the analysis, results were exported to FEA software to create maps for visualization of von Mises stress, maximum principal stress $(\mathrm{MPa})$ and microstrain $(\mu \varepsilon)$ on bone tissue and in the implants/components (MegaPascal $(\mathrm{MPa})$ unit).

\section{Results}

\section{Implants/abutment/crown (von Mises stress analysis)}

All models showed a similar stress pattern for the analyzed models. Lower stress distribution was observed for models in $0^{\circ}$ loading (20-45 MPa), and higher stresses were observed in $60^{\circ}$ loading with overload in the abutment region, as well as near the cervical region of the implant (185-270 MPa). The M3 model showed a little relief of the stress in the apical region of the implant compared to the M1 and M2 models (Figure 2). 
Figure 2: Von Mises stress analysis (implants/abutment/crown).

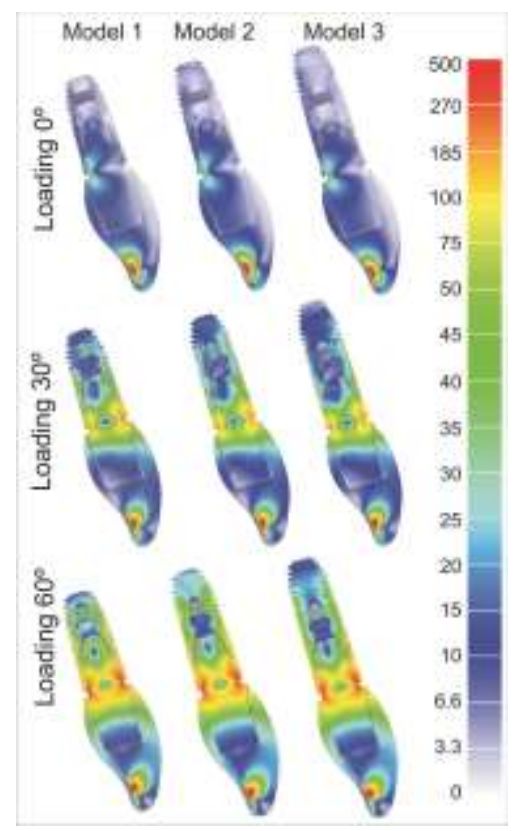

Source: Authors.

\section{Cortical/Trabecular bone tissue (Maximum Principal Stress analysis)}

In the sagittal sections, in the axial $\left(0^{\circ}\right)$ and $30^{\circ}$ loading showed similarity in the stress distribution for evaluated models, while under the $60^{\circ}$ loading, the conventional technique with short implants (M1) showed more tensile stress in the cortical bone tissue when compared to bicortical techniques with longer implants (M2 and M3). However, no differences were observed between bicortical (M2) and bicortical with nasal floor elevation (M3) technique (Figure 3).

Figure 3: Maximum Principal Stress analysis (cortical/trabecular bone tissue).

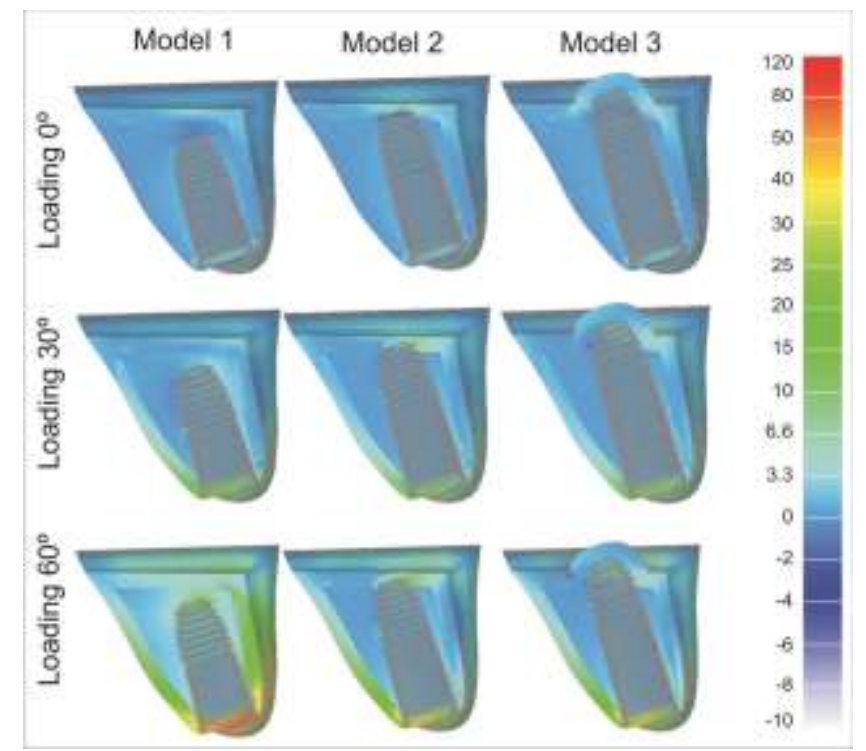

Source: Authors. 


\section{Cortical/Trabecular bone tissue (Microstrain analysis)}

In the axial loading the models presents similarity in the microstrain between all models, with slight increase strain ( 1150-1380 $\mu \varepsilon$ ) around implant for trabecular bone of M1. In the $30^{\circ}$ and $60^{\circ}$ loads, these differences are more evident for conventional technique (M1) that showed higher microstrain (up to $6000 \mu \varepsilon$ ) in the cortical and trabecular bone tissue when compared to the bicortical models (M2 and M3). However, no differences were observed between bicortical bone anchorages (M2 and M3) (Figure 4).

Figure 4: Microstrain analysis (cortical/trabecular bone tissue).

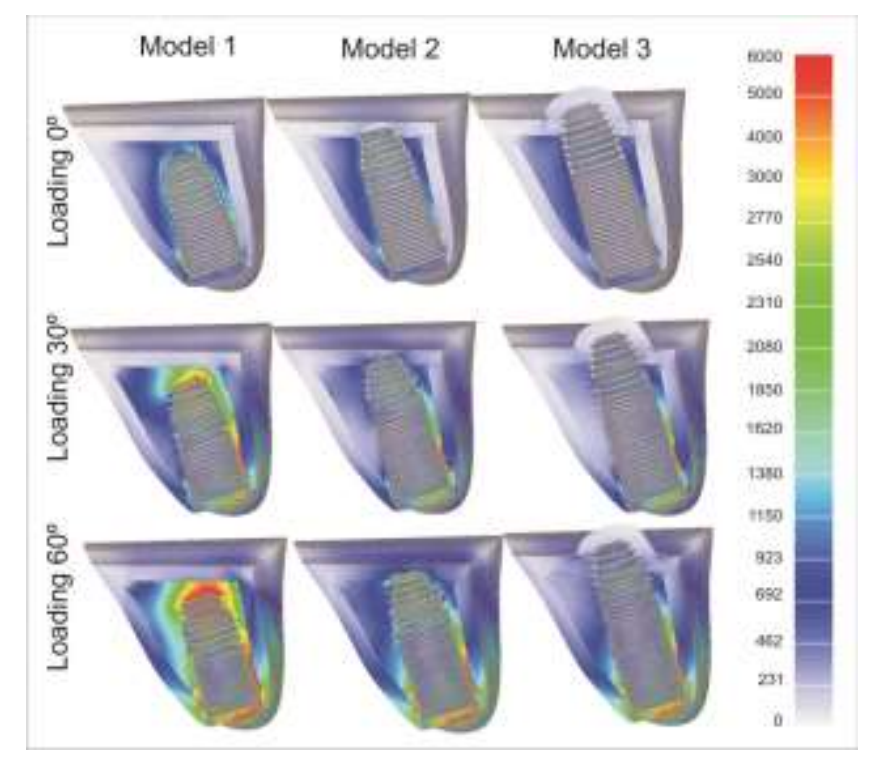

Source: Authors.

\section{Discussion}

The hypothesis tested was rejected, since there was difference in the stress distribution between the bone anchorages evaluated. These results corroborate with previous studies which reported that bicorticalization technique should be preferred due to better stress distribution in bone tissue and implant/components (Verri et al., 2017; Verri et al., 2017(2)). In this study Morse taper implants were simulated because have greater internal stability and centralization of stresses than other connections (Verri et al., 2017; Verri et al., 2017(2); Lemos et al., 2016; Minatel et al., 2017), and this which could attenuate the bicorticalization effect. Even so, bicortical techniques showed more efficient for stress distribution for the simulated conditions even in Morse taper implants. These results are important because actually Morse taper implants has been used with higher frequency for rehabilitation in the maxillary anterior region due to aesthetic, guaranteeing the maintenance of the crestal bone tissue and papillary aesthetics (Mangano et al., 2012). So, the biomechanical influence of the surgical technique could contribute for clinicians when choosing to use a longer implant with a bicortical anchorage, especially in situations of immediate loading (Ahn et al., 2012; Han et al., 2016; Strub et al., 2012).

Huang et al. (2009) reported that bicortical anchorage contributed to decrease approximately $50 \%$ stress in the cortical and trabecular bone tissue when compared with conventional/monocortical anchorage. Similar results were obtained in this study. This fact could be justified because the implant placement with bicorticalization technique increase the removal torque, and consequently the implant primary stability as compared with monocortical anchorage (Ahn et al., 2012). However, controversy can be observed in the literature stating that the biomechanical behavior of bicorticalized implants could be unfavorable and would increase stress in the cortical bone (Kan et al., 2015) at a level that would be undesirable for 
osseointegration (Ivanoff et al., 2000). These difference, can be attributed to the absorption of traumatic forces by the trabecular bone during the placement of the implants, having a lower traumatic effect when placed in monocortical anchorage (Kan et al., 2015), guaranteeing predictability and safety of the technique (Faria et al., 2016).

In this study, some data are considered physiological by Frost, 2003 that reported around $60 \mathrm{MPa}$ and $3000 \mu \varepsilon$ for bone's operational microdamage threshold range. In this way, the non-axial loading (especially $60^{\circ}$ ) for conventional technique could be considered unsafe. These results are in agreement with the literature that can be observed worse biomechanical behavior in oblique (non-axial) loads. However, no dynamic physiology of bone was simulated in this study which could be reach up to different results and this could be considered a limitation of analysis.

Besides, considering $30^{\circ}$ and $60^{\circ}$ situations, the results always showed up to limit values of Frost in some areas for conventional techniques, being less preferable than bicortical situations, since pathological overload leads to greater risks of bone resorption (Frost et al., 2003). Thus, the use of bicortical techniques can be recommended mainly in immediate loading due to the increase in the primary stability of the implants (Ahn et al., 2012; Han et al., 2016). The increase in the primary stability could be associated with better biomechanical behavior to increase the implants survival rate.

In this study, $10 \mathrm{~mm}$ bone availability was simulated to short implant placement $(8.5 \mathrm{~mm})$ with conventional technique, while in the other models was simulated standard lengths (10.0 mm and $11.5 \mathrm{~mm}$ ) (Telleman et al., 2011). So, considering that short implants are classified differently in each study $(\leq 8.5 \mathrm{~mm}, \leq 7 \mathrm{~mm}$ ) (Cruz et al 2018; Guida et al 2019) and extra short ( $\leq 6 \mathrm{~mm}$ ) (Guida et al 2019), besides the surgical technique, the length of the implants may have influenced these results, since short implants present a worse biomechanical behavior (Kan et al., 2015), and consequently a higher risk of failures (Lemos et al., 2015; Gonçalves et al., 2015). Although, the difference of length in $1.5 \mathrm{~mm}$ was not significant to observed difference in the bicortical techniques $(10 \mathrm{~mm}$ to $11.5 \mathrm{~mm})$. Considering this, bone anchorage represent a greater influence in the biomechanical behavior than the length of the implant.

Even so, it can be highlighted that bicortical technique associated with nasal floor elevation demands more ability of surgeon due to troubles reported in this technique, such as bleeding, swelling, pain, hematoma, infection, implant displacement, rhinitis, and sinusitis (Mazor et al., 2012; Kfir et al., 2012; Felisati et al., 2013) and still possibility of pushing the implant for the nasal cavity. So, this technique is more difficult than simple bicortical technique.

These results should be interpreted with caution, since the bone tissue was considered isotropic, linear, and homogeneous and under static linear analysis. However, results from FEA studies permit a better understanding of biomechanical behavior in individualized structures. These results might be carefully extrapolated to the diary clinic. One additional limitations of this study was the use of Morse taper implants at the crestal bone level. It was suggested that subcrestal placement of Morse taper implants could be for long-term stability bone tissue (Catro et al., 2014), as well as better biomechanical characteristics (Sotto-Maior et al., 2014), however, implant placement at the bone level was performed to compare with other connections previously published (Verri et al., 2017; Verri et al., 2017 (2)), and evidences evaluated in the systematic review by Cruz et al 2020, conclude that in terms of implant-supported restoration survival and peri-implant tissue parameters both approaches of implant treatments are clinically acceptable. Finally, the statistical analysis would be able to improve the interpreting of the results (Lemos et al., 2016; Minatel et al., 2017; de Souza Batista et al., 2017; Pellizzer et al., 2018), showing quantitative analysis but, in the present study, the maps of stress and strain were very clear avoiding the bias in the interpretation. Thus, the statistical analysis was not applied as previous studies in FEA (Verri et al., 2017; de Souza Batista et al., 2017 (2); Lazari et al., 2014; Toniollo et al., 2017; Lemos et al., 2018). 


\section{Conclusion}

Within the limitations of this study can be conclude that bicortical techniques (with or without nasal floor elevation) presented lower stress and strain in bone tissue without difference between two bicortical techniques. The nonaxial loading showed higher stress and microstrain in the bone tissue and implants/components.

\section{Acknowledgments}

The authors would like to express gratitude to Renato Archer Research Center, Campinas, São Paulo, Brazil, and Conexão Sistemas de Prótese, Arúja, São Paulo, Brazil.

\section{Funding}

Supported by National Council for Scientific and Technological Development (CNPq) -grant (130312/2015-0)

\section{References}

Ahn, S. J., Leesungbok, R., Lee, S. W., Heo, Y. K., \& Kang, K. L. (2012). Differences in implant stability associated with various methods of preparation of the implant bed: an in vitro study. J Prosthet Dent. 107(6): 366-72.

Castro, D. S., et al. (2014). Comparative histological and histomorphometrical evaluation of marginal bone resorption around external hexagon and Morse cone implants: an experimental study in dogs. Implant Dent. 23(3):270-6.

Cruz, R. S., et al. (2018). Short implants versus longer implants with maxillary sinus lift. A systematic review and meta-analysis. Braz Oral Res.32:e86.

Cruz, R. S., et al. (2020). Clinical comparison between crestal and subcrestal dental implants: A systematic review and meta-analysis. J Prosthet Dent. S00223913(20)30691-0.

de Souza Batista, V. E., et al. (2017) Finite element analysis of implant-supported prosthesis with pontic and cantilever in the posterior maxilla. Comput Methods Biomech Biomed Engin. 20(6): 663-670. (2)

de Souza Batista, V. E, et al. (2017). Evaluation of the effect of an offset implant configuration in the posterior maxilla with external hexagon implant platform: A 3-dimensional finite element analysis. J Prosthet Dent. 118(3): 363-371.

Faria PE, et al. (2016). Immediate loading of implants in the edentulous mandible: a multicentre study. Oral Maxillofac Surg. 20(4): 385-390.

Felisati G, et al. (2013). Sinonasal complications resulting from dental treatment: outcome-oriented proposal of classification and surgical protocol. Am $J$ Rhinol Allergy. 27(4): e101-6.

Frost, H. M. (2003). Bone's mechanostat: a 2003 update. Anat. Rec. A Discov. Mol. Cell. Evol. Biol. 275: 1081-1101.

Goiato M. C, et al. (2014). Longevity of dental implants in type IV bone: a systematic review. Int J Oral Maxillofac Surg. 43(9):1108-16.

Gonçalves, T. M, et al. (2015). Long-term Short Implants Performance: Systematic Review and Meta-Analysis of the Essential Assessment Parameters. Braz Dent J. 26(4): 325-36.

Guida, L, et al. (2020). 6-mm-short and 11-mm-long implants compared in the full-arch rehabilitation of the edentulous mandible: A 3-year multicenter randomized controlled trial. Clin Oral Implants Res. 31(1):64-73

Han, H. C, et al. (2016). Primary implant stability in a bone model simulating clinical situations for the posterior maxilla: an in vitro study. $J$ Periodontal Implant Sci. 46(4):254-65.

Huang, H.-L., et al. (2009). Biomechanical effects of a maxillary implant in the augmented sinus: a three-dimensional finite element analysis. The International Journal of Oral\&Maxillofacial Implants. 24(3): 455-62.

Ivanoff, C. J., et al. (2000). Influence of bicortical or monocortical anchorage on maxillary implant stability: a 15-year retrospective study of Brånemark System implants. Int J Oral Maxillofac Implants; 15(1): 103-110.

Kan, B, et al. (2015). Effects of inter-implant distance and implant length on the response to frontal traumatic force of two anterior implants in an atrophic mandible: three-dimensional finite element analysis. Int J Oral Maxillofac Surg. 44(7): 908-13.

Kfir, E, et al. (2012). Minimally invasive subnasal elevation and antral membrane balloon elevation along with bone augmentation and implants placement. $J$ Oral Implantol. 38(4): 365-76.

Lazari, P. C., et al. (2014). Influence of the veneer-framework interface on the mechanical behavior of ceramic veneers: a nonlinear finite element analysis. $J$ Prosthet Dent. 112(4):857-63. 
Lekholm, U., \& Zarb, G. A. (1985). Patient selection and preparation. In: Brånemark, P.I., Zarb, G.A., Albrektsson, T. (Eds.), Tissue-integrated Prostheses. Osseointegration in Clinical Dentistry, Quintessence, Chicago, pp. 199-209.

Lemos, C. A., et al. (2016). Short dental implants versus standard dental implants placed in the posterior jaws: A systematic review and meta-analysis. $J$ Dent. 47:8-17.

Lemos, C. A. A., et al. (2018). Retention System and Splinting on Morse Taper Implants in the Posterior Maxilla by 3D Finite Element Analysis. Braz Dent J. 29(1):30-35.

Limbert, G., et al. (2010). Trabecular bone strains around a dental implant and associated micromotions--a micro-CT-based three-dimensional finite element study. J Biomech. 43(7):1251-61.

Mangano, F., et al. (2012). Single-tooth Morse taper connection implants placed in fresh extraction sockets of the anterior maxilla: an aesthetic evaluation. Clin Oral Implants Res. 23(11): 1302-7.

Mazor, Z., et al. (2012). Nasal floor elevation combined with dental implant placement. Clin Implant Dent Relat Res. 14(5): 768-71.

Minatel, L., et al. (2017). Effect of different types of prosthetic platforms on stress-distribution in dental implant-supported prostheses. Mater Sci Eng C Mater Biol Appl. 71:35-42.

Pellizzer, E. P., et al. (2018). Biomechanical analysis of different implant-abutments interfaces in different bone types: An in silico analysis. Mater Sci Eng C Mater Biol Appl. 90: 645-650.

Santiago Junior, J F., et al. (2016). Finite element analysis on influence of implant surface treatments, connection and bone types. Mater Sci Eng C Mater Biol Appl. 63: 292-300.

Sertgöz, A. (1997) Finite element analysis study of the effect of superstructure material on stress distribution in an implant-supported fixed prosthesis. Int $J$ Prosthodont. 10(1):19-27.

Sevimay, M., et al. (2005). Three-dimensional finite element analysis of the effect of different bone quality on stress distribution in an implant-supported crown. J Prosthet Dent. Mar;93(3):227-34.

Sotto-Maior, B. S., et al. (2014). Biomechanical evaluation of subcrestal dental implants with different bone anchorages. Braz Oral Res.

Strub, J. R., et al. (2012). Prognosis of immediately loaded implants and their restorations: a systematic literature review. J Oral Rehabil. 39(9):704-17.

Telleman, G., et al. (2011). A systematic review of the prognosis of short $(<10 \mathrm{~mm})$ dental implants placed in the partially edentulous patient. $J$ Clin Periodontol. 38(7): 667-76.

Toniollo, M. B., et al. (2017). A Three-Dimensional Finite Element Analysis of the Stress Distribution Generated by Splinted and Nonsplinted Prostheses in the Rehabilitation of Various Bony Ridges with Regular or Short Morse Taper Implants. Int J Oral Maxillofac Implants. 32(2): 372-376.

Verri, F. R., et al. (2016). Can the modeling for simplification of a dental implant surface affect the accuracy of 3D finite element analysis? Comput Methods Biomech Biomed Engin. 19(15): 1665-72.

Verri, F. R., et al. (2017). Influence of bicortical techniques in internal connection placed in premaxillary area by 3D finite element analysis. Comput Methods Biomech Biomed Engin. 20(2):193-200. (2)

Verri, F. R., et al. (2017). Biomechanical Three-Dimensional Finite Element Analysis of Single Implant-Supported Prostheses in the Anterior Maxilla, with Different Surgical Techniques and Implant Types. Int J Oral Maxillofac Implants. 32(4): e191-e198.

Verri, F. R., et al. Three-Dimensional Finite Element Analysis of Anterior Single Implant-Supported Prostheses with Different Bone Anchorages. ScientificWorldJournal. 2015; 2015:321528. 